\title{
Twenty-nine years of the BIR annual survey part 2: changing information work
}

\section{Luke Tredinnick}

Abstract: This paper is the second part of a review of the Business Information Review Annual Survey, which has been published annually since 1991. The paper explores changes to the professional context for information work revealed by the surveys over the course of its publication. It uses a combination of content and thematic analysis to develop key themes, which are discussed by reference to the original surveys: the decline of public library business services; changing budgets; globalisation of business information; offshoring and outsourcing of information work; rising up the value chain; changing skills in information work; reliability and accuracy of information; and rising up the value chain. The paper aims to summarise and consolidate longitudinal trends revealed by the survey, act as a guide to the rich data contained within the surveys themselves, and provide a testament to the wealth of professional experience captured in the BIR Annual Surveys. Its findings relate to the changes in the nature of professional practice and the pressures on professional practice over the past thirty years.

\subsection{Introduction}

The Business Information Review (BIR) Annual Survey is the world's longest-running research project into trends in the business information sector. Since 1991 it has provided invaluable insights into changes in business information work and the contexts within which that work takes place.

From the early days of the survey, the value of the longitudinal data it was collecting was recognised. In 1993 for example it was written that "as the survey moves into its third year, it becomes possible to start tracking changes in the use of business information, as well as documenting the emergence of new trends" (Headland Press, 1993: 2). Since then individual surveys have frequently reflected short- and medium-term trends, and in 2000 the report included a useful summary of the first ten years of findings (Smith, 2000: 19 - 21). However there has been no systematic summary of the changes revealed by the survey over the three decades of its publication. This review seeks to close that gap, analysing what the BIR Annual Survey reveals about how information work has changed over three decades, and exploring what this implies about the future. It is divided into two parts. The first part of this review presented in September 2019 (Tredinnick, 2019) addressed technological change; the second part presented here addresses changes to the nature of information work.

Taken together the surveys represent an incredibly rich data-source. Twenty-seven surveys have been published between 1991 and 2018, comprising some 497 pages, 500 data tables and diagrams, and around 250,000 words. Reading them in sequence impresses the amount of change through which business information work has gone, but also strong continuities in key concerns, challenges, and values underlying the profession. This review can only touch on the richer detail that emerges in the rich data of the surveys themselves, and there is much to discover from returning to the original reports. This paper is therefore intended as a summary of key trends within the survey rather than a comprehensive review, and readers are encouraged to follow-up on key issues within the annual surveys themselves.

This review uses content and thematic analysis to explore change over time. The published surveys between 1991 and 2018 were read in-depth, and the data was coded according to an ad hoc scheme reflecting the shifting priorities of the surveys. From this coding seven key themes were developed for discussion in this paper:

1. The decline of public library business services;

2. Changing budgets;

3. Globalisation of business information;

4. Offshoring and outsourcing information work;

5. Changing skills in information work;

6. Information quality and reliability; 
7. Rising up the value chain.

These complement the technological themes explored in the first part of this review (Tredinnick, 2009):

1. The telling case of CD-ROMs;

2. The Internet and the World Wide Web;

3. Changing information formats;

4. The impact of digital technologies on information work;

5. Intranets and knowledge management (KM);

6. Newer technologies.

The aims of both parts of this review are threefold. In the first place, they aim to summarise and consolidate longitudinal trends in the development of business information services over a period of rapid change between 1991 and 2018. Secondly, they aim to act as a guide to the rich data that is contained within the surveys themselves, by highlighting where particular issues first emerge, and how they develop through the years. Finally, they aim to testify to the wealth of professional experience than has been captured through the annual snapshots of the profession. Over the past thirty years, hundreds of individuals have taken part in the BIR Annual Survey, giving over time and volunteering experience to benefit the wider professional community. The success of the Annual Survey has depended on the insights gained from these contributions.

\subsection{Overview of the Business Information Review Annual Survey}

Like any long-running piece of research the BIR Annual Survey has undergone a number of changes in scope, focus, methodology and authorship. A fuller account of these changes is presented in the first part of this review (Tredinnick, 2019). However, some aspects particularly relevant to the development of professional practice and professional values are reiterated here.

The survey was first published in 1991 with the expressed aim to "establish which products and services are used most heavily in UK business libraries and information departments" (Headland Press, 1991: 11). Since that time four people have been involved in producing the BIR Annual Survey. Between 1991 and 2001 the survey was conducted and written by Gerry Smith (initially under the byline of Headland Press and Headland Business Information). From 2002 to 2016 the survey was written and conducted by Allan Foster and Pam Foster (2002 - 2003), Pam Foster and Allan Foster (2004 - 2006), and Allan Foster (2007 - 2016). Since 2016 the research has been undertaken by Denise Carter of DCsion Consult.

Soon after it began the survey outgrew its original narrow focus on resources, products and services, and began to explore strategic and professional issues. Nevertheless changes to the research design have tended to be evolutionary rather than revolutionary and reflect the changing contexts within which the survey has been undertaken. There has been one major change in approach and several small changes in focus over the history of the research. Between 1991 and 2006 the research was undertaken using survey methodology; for the majority of this time postal questionnaires were mailed to publisher or information service subscriber lists, but from 2003 the postal questionnaire was supplemented by an electronic questionnaire distributed via special interest groups (Foster \& Foster, 2003), and from 2005 it was supplemented by a smaller survey targeted at key information professionals in the corporate sector (Foster \& Foster, 2005). From the late 1990s there was a significant decline in the response rate to the general survey (see: figure 1); this perhaps reflected the consolidation of librarianship and information management in the business sector. By 2006 the continuing viability of a general survey was becoming questionable. This prompted a change in approach; writing about this fundamental rethink Allan Foster wrote:

This arrangement staggered on for a number of years before, in 2006, the responses became more uneven, prosaic, arbitrary and less and less representative of the corporate business 
environment where much of the interesting service development was happening. (Foster, 2008: 14)

From 2007 the BIR Annual Survey adopted a rich, qualitative and in-depth approach using interviews with key senior professionals as its principle research instrument, supplemented by insights from the professional literature. It has continued to use in-depth interviews with key information professionals ever since. However in 2017 a smaller scale survey was reintroduced to compliment the qualitative findings. These changes in methodology and approach make it more difficult to draw direct comparisons between the two periods, although it is still possible to draw inferences across the data.

This change from surveys to interviews accompanied a shift in scope and focus from products and services to strategic, policy and management issues. The 2007 report explained:

The concentration in this Survey is on strategic issues - the place of the information service in the organization, the role of knowledge management in the business, whether or not to provide training in the use of desk top data sources, the possible use of outsourcing or offshoring and the use of performance measures in assessing the value the information service adds to the business (Foster, 2007).

The switch to interviews also narrowed the sector scope of the survey. Between 1991 and 2006 the survey covered a range of information sectors - predominantly corporate, academic and public libraries. The proportion of respondent from different sectors remained relatively stable over time (figure 1) however towards the end of this period the corporate sector became significantly more important to the survey. From 2007 the survey began to address trends within the corporate sector in order to provide "a very clear focus to the survey and allows a measure of in-depth comparison and benchmarking which has proved difficult in the past (Foster, 2007: 14). It has largely retained this narrower focus since. More recently the research has expanded its geographical scope; in 2017 the survey reported that "The breadth of the survey is now truly international, with respondents from UK, Europe, Asia, Australia and North America" (Carter, 2017: 122). The shifting sampling strategy makes it more difficult to draw reliable inferences from the statistical data over time, however the duration of the research mitigates some of these issues. Where it is possible to disaggregate subsamples this review has focussed on responses from the corporate sector, in keeping with the current focus of the BIR Annual Survey.

Figure 1: Responses by sector over time

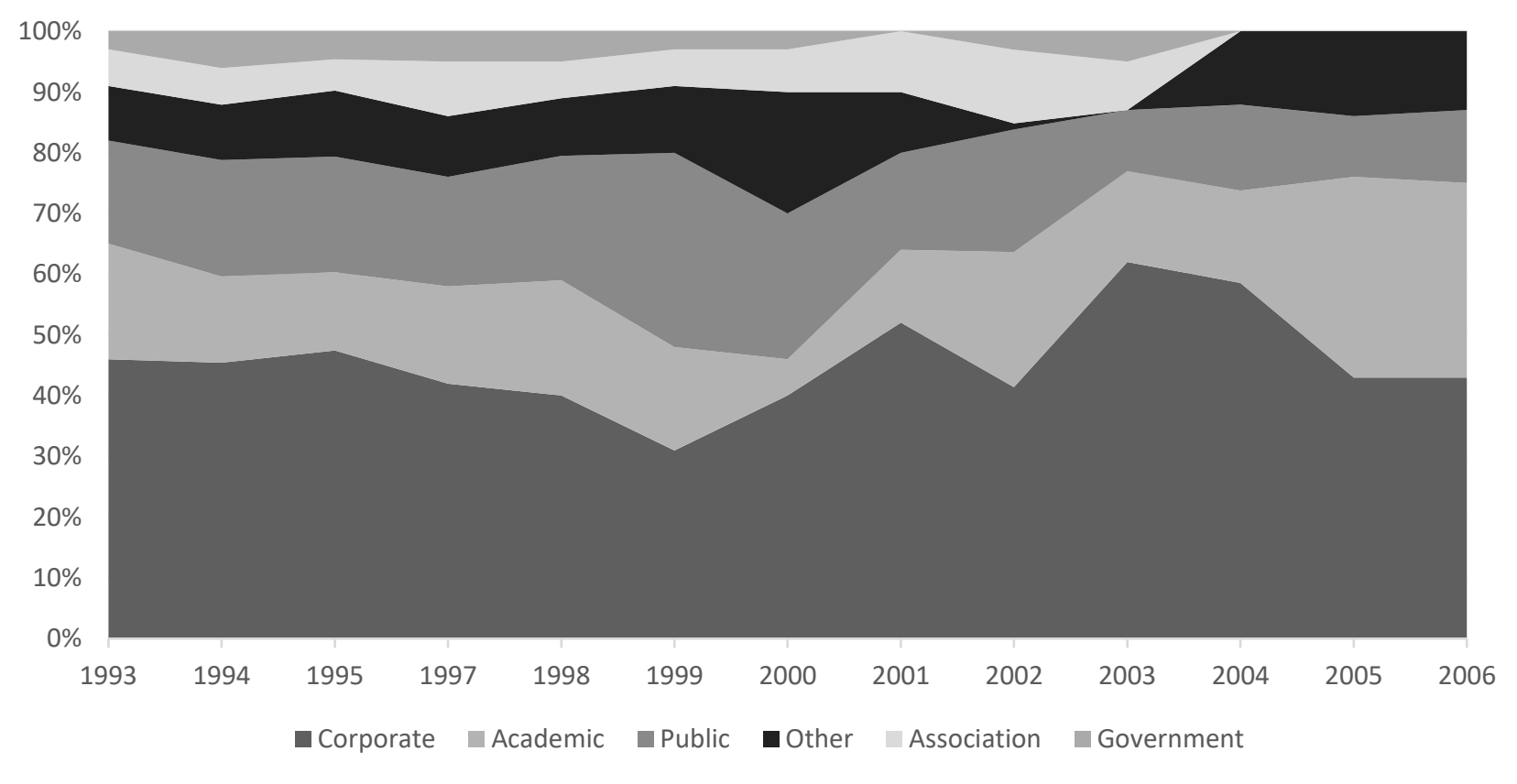


From 2007 participants in the survey interviews and from 2017 survey questionnaire are recorded by sector; the distribution is shown in figure 3 below. The commentary is this review has tended not to disaggregate issues by sector except in one or two contexts, however the richer data of the original reports still holds valuable insights into sector trends.

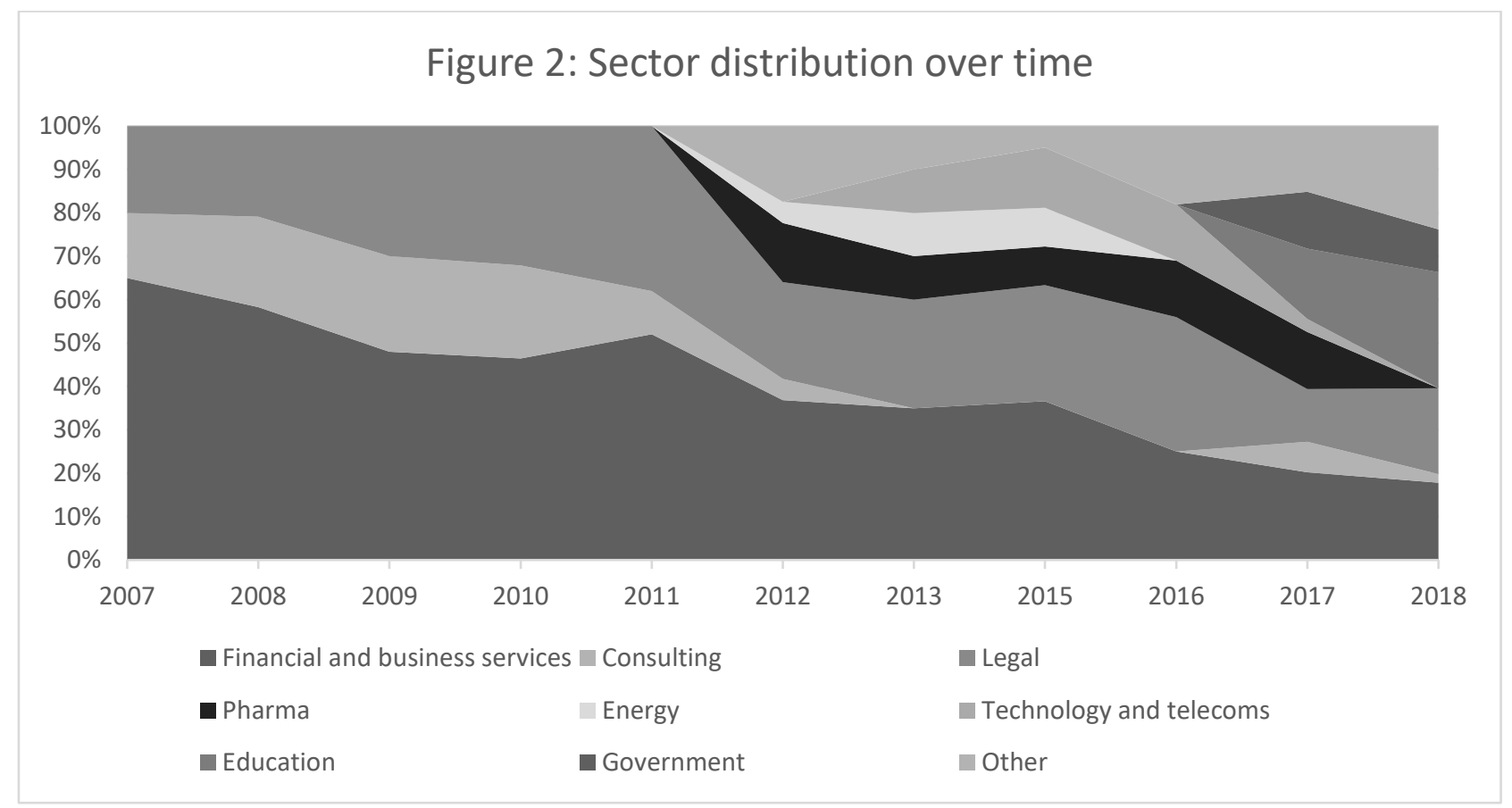

Over its entire run almost 2000 completed questionnaires and over 200 interviews have been included in the research. Although participation in the research has always been anonymous, we are aware that many of the participants in the BIR Annual Survey have lent their insights, expertise over many years, and the research has been indebted to, and dependent on everyone who has taken part in it.

\section{Part 2: Changing information work}

The first part of this review (Tredinnick, 2019) explored that way in which technological change has emerged though the BIR Annual Surveys. This second part examines the way in which working lives, practices and values have changed over the same period. Since 1991 there has been a significant change in the nature of information work within corporate contexts. This change has been influenced by the kinds of technological changes that were explored in the first part of this review, but they have also been influenced by the shifting context of business information work. Some aspect of this is captures in figures 3 and 4 below. Some aspect of this is also captured in the key findings of the surveys presented in Appendix 2. 


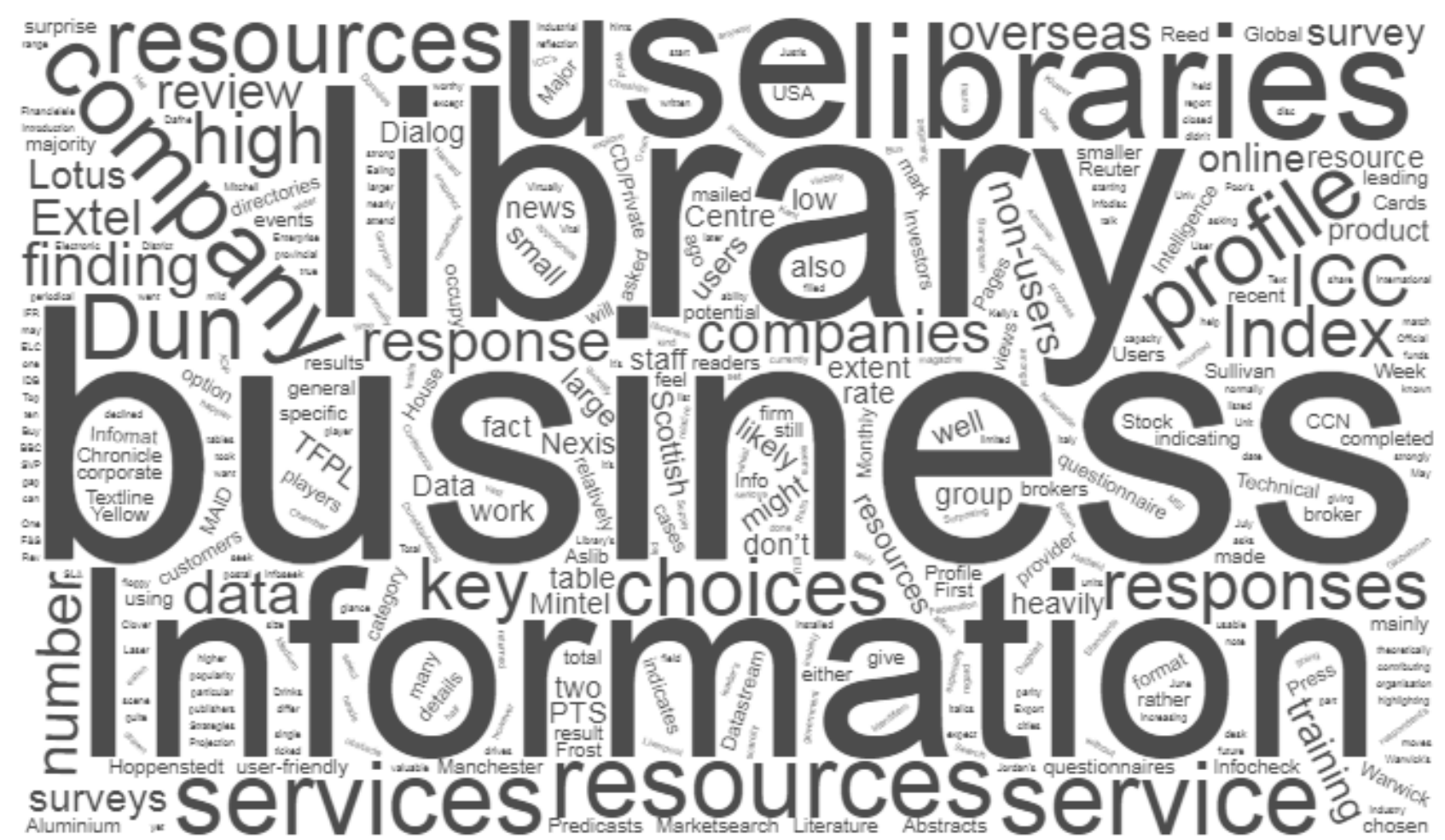

Figure 3: Word cloud generated from 1991 Annual Surve7

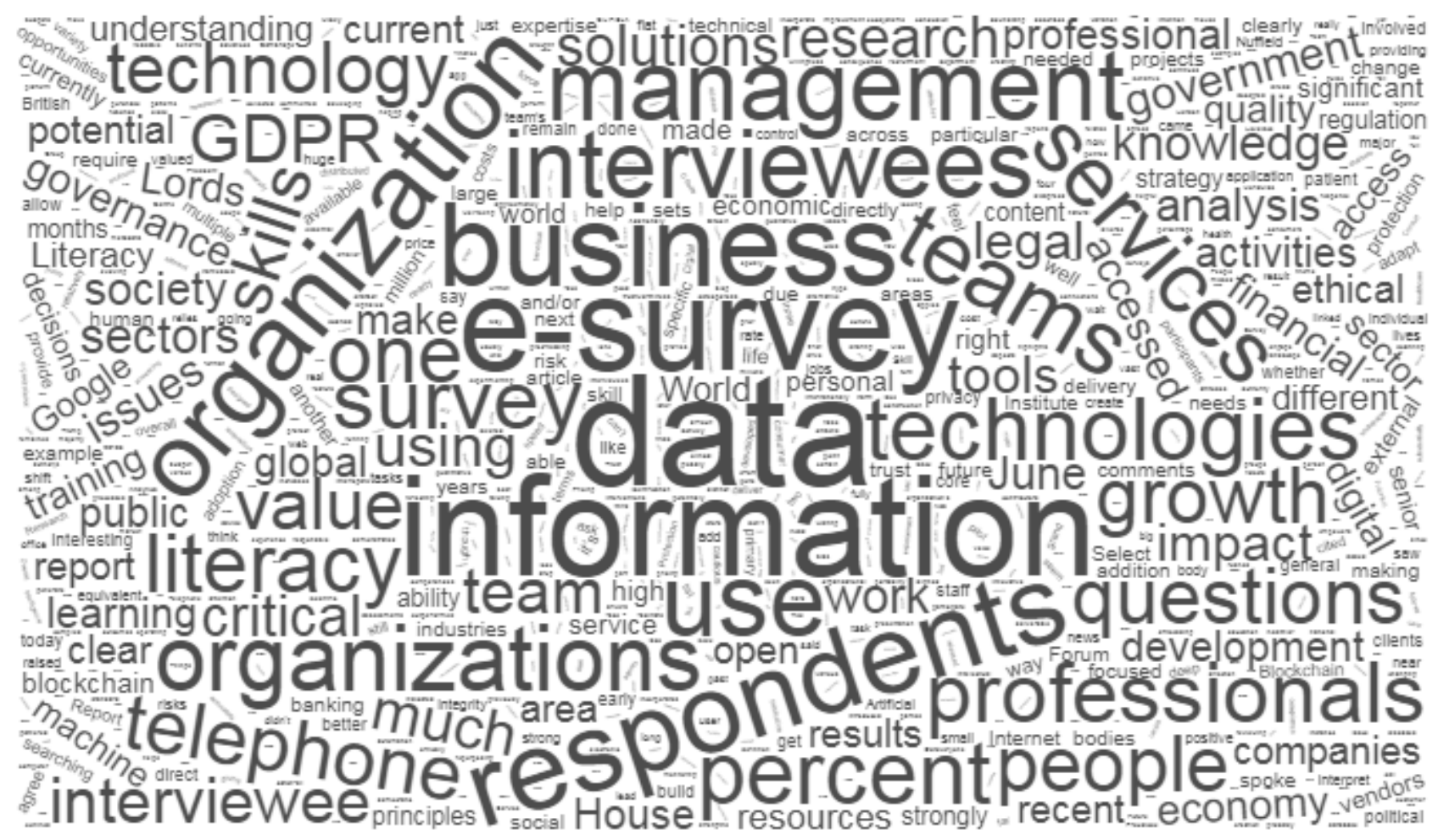

Figure 4: Word cloud generated from 2018 survey

The BIR Annual Survey has tracked many of these changes, revealing both the extent to which professional practice has changed over time, and the strong continuity in professional values.

Theme 1: The decline of public library business services 
In recent years the crisis in public librarianship has come to the fore. With budgets stretched as a consequence of economic austerity measures put in place after the credit crunch of 2017 and subsequent financial crisis, local authorities and other public bodies have sought to reduce expenditure on public library services by closing branches, reducing opening hours, or reducing the number of professional staff. In 2018 for example the annual survey of British libraries by the Chartered Institute of Public Finance and Accountancy (Cipfa) revealed that 127 public or mobile libraries had closed over the previous year, a figure in line with annual closures of public libraries since 2010 (Cipfa, 2018). Over the same period public library services lost 712 full-time employees (Cipfa, 2018). One contributory cause to the decline of public library service sometimes cited has been the growing adoption of the Internet and World Wide Web. As information has become more available, the use of public libraries has declined.

The BIR Annual Survey does not track these more recent changes. This is because by 2010 public library business services had already become largely irrelevant to information and knowledge management in the commercial sector for the large and medium sized companies that feature in our survey. The surveys reveal a dramatic collapse in demand for public library business services in the early 2000s, as information and knowledge managers in the commercial sector sought other ways of sourcing business information, largely through web-based platforms. It also reveals anxiety amongst business librarians in the public library sector about how to adapt to these challenges.

From its very first year the survey asked about the use of public libraries and information brokers by business information professionals in the UK. Through the early nineteen-nineties the resources of business library and information centres were frequently supplemented by drawing on public library collections, and by the use of information brokers. This is most obviously the case for London based companies, who could draw on the established services of the Science Reference Library, City Business Library, and Westminster Central Reference Library, which regularly featured as the top three public library services used by business information professionals in the BIR Annual Survey. However, in total 19 publically available library services are mentioned by respondents during this period. Westminster Central Reference Library and the British Library also featured as two of the top information broker services in use at this time.

In 1991 for example almost $80 \%$ of respondents use publically available library services and about half use information brokers (Headland Press, 1991). By 1995 this had remained broadly unchanged, prompting the observation:

The long list of public business libraries outside London "written in" by respondents is an indication of a thriving network of provincial business information resources. Many librarians rely on their local business information resource. (Headland Business Information, 1995: 7)

Public library collections were clearly a valuable resource for commercial organisations. However, after 1995 the use of publically accessibly libraries begins to decline. In 1997 the survey notes that "business librarians appear to be making less use of complementary resources in public business libraries" (Smith, 1997: 1) and suggests "there is a hint that we are witnessing the start of a trend" (Smith, 1997: 1). This proves prescient; by 2002 the survey reveals "a sector struggling to redefine a business information role 'in a post-Internet era'" (Smith, 2002: 21). The 2003 survey expands on these challenges and is worth quoting in full:

Of all the sectors represented in the Survey, public business librarians appear to be experiencing the most serious 'strategic re-positioning' challenges [...] There are fundamental changes being brought about, for so many members of the public, by easy Internet access at home and/or work. Hardly surprising then that there has been a decline in conventional business reference enquiries. If our respondents are anything to go by then business libraries are having to discover a series of new roles, including, in particular, training their staff to be able to work in this increasingly digital information landscape. But fundamental questions remain. As one of our respondents put it 'in order to find our niche again, we are uncertain whether to go more specialized or keep general, and whether we can market our search skills' (Smith, 2003: 23). 
By 2004 public library services "continue to face a crisis of confidence and role" (Foster \& Foster, 2004: 13). As the public library sector declines, the experiences of public librarians feature less and less prominently in the survey. Figure 1 above shows the proportion of all responses from the public library sector over time until 2006 after which the survey began to focus more exclusively on the corporate sector.

The survey reveals a contraction of public library business services, but also a shift in their userbase, and these challenges are consistently linked to the growth of web-based resources. Nevertheless the commercial organisations reflected in the BIR Annual Survey tend to be medium to large, and very often international. This is not unconnected to budgetary issues discussed below. Over time, perhaps, the value of information to commercial organisations has increased, and the comparative cost of information has declined. The barriers to accessing public library business services - particularly time and location - perhaps grow in significance as alternative sources of information proliferate.

These changes are of course largely familiar to anyone who has worked in an information management role throughout this period. As the speed of information discovery and delivery has increased, the time-factor in accessing information has become more important. Nevertheless it also perhaps testifies to the ways in which information work has changed, particularly with respect to the speed at which information is delivered in a contemporary corporate context. Public library business services still play an important role supporting a range of small business. Yet there is no question that the nature of the audience for these services has dramatically shifted. There are also perhaps unintended consequences of this change, as large commercial organisation become less rooted in their local geographical contexts, and less dependent on local services. There are also broader consequences perhaps for the professional identity of information professionals in the corporate sector in this loss of shared interests and concerns with public librarians.

\section{Theme 2: Changing budgets}

One of the driving influences on information work over time has been available budgets. The BIR Annual Survey has tracked changes in the budgets of information centres since its inception, although not always in a consistent way. Nevertheless there emerges a clear picture: organisations in the commercial sector spend more on business information resources over time, although that does not always reflect investment in information professionals. Furthermore the growth in budgets perhaps also reflects the consolidation of business information management in fewer, larger organisations.

Prior to 1998 the survey periodically asked about changes in resource budgets and budgets for specific resources. The questions are of a kind that make it difficult to draw wider conclusions from the data. For example, in 1992 the survey asks about budgets for information broker services but not for information services in general (Headland Press, 1992). It also asks about cuts to resource budgets, but not whether budgets have increased. Because the most common response to these latter questions is that budgets have not been cut, the survey does not reveal whether or not they remained static or increased. Budgetary questions are posed in the same way the following year (Headland Press, 1993), and while the survey does appear to reveal a significant impact of the early 1990s recession, the leading way in which this issue is framed creates problems in extrapolating trends. For the next two surveys there are no questions related to budgets, although budgetary constraints do feature prominently in the qualitative feedback particularly as a key challenge in the provision of services. In 1997 the survey once again asks about resource budgets, but this time only asks whether those budgets have increased, decreased or stayed the same (Smith, 1997). As there is no benchmark for these changes they are of little wider value.

Nevertheless between 1998 and 2014 there is a consistent tracking of budgets that allows extrapolation of some long-terms trends (figure 5). These reveal a consolidation of spending in the 
middle and upper end of the spectrum of services tracked by the survey. That is to say that over time more organisations are spending more money on resources. In 1998 well over half of respondents were spending less than $£ 50,000$ per annum on resources (Smith, 1991); by $2014100 \%$ of respondents had a larger budget than this (Foster, 2014). At the other end of the spectrum only $20 \%$ of the respondents had a resources budget greater than $£ 100000$ in 1998, but by 2014 that had risen to $95 \%$ of respondents. The rise is only partially accounted for by inflation over the period; clearly other factors are also at play.

\section{Figure 5: Resource budgets as a proportion of}

\section{respondents}

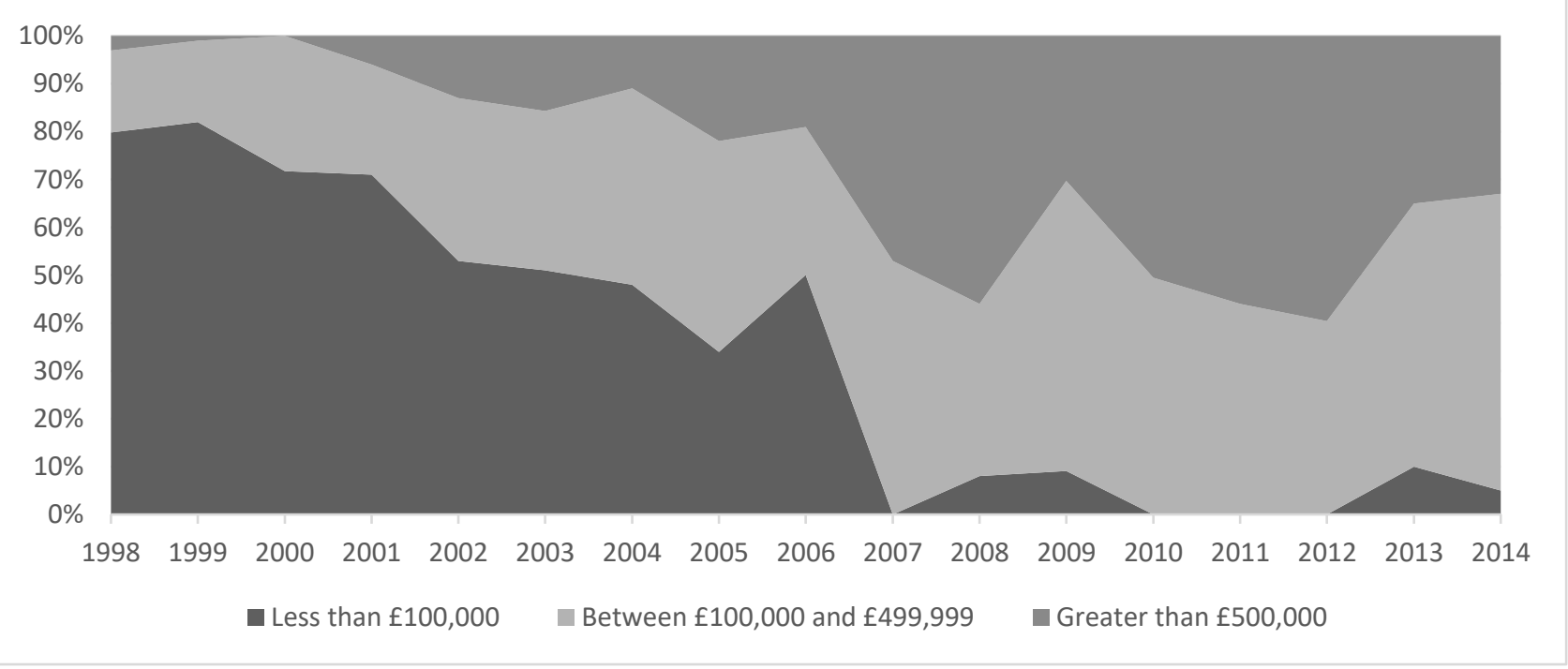

One explanation of this shift is the changing sample captured by the survey. For its first decade a significant proportion of respondents to the survey came from academic and public library sectors. This declines significantly in time. The 2004 survey itself observes that it is somewhat simplistic to suggest that the wide disparity in resource budgets is fully accounted for by differences in spending power of corporate, public, and academic libraries as is sometimes implied in the early years of the survey (Foster \& Foster, 2004). Nevertheless the drop-off of academic and public libraries, and the decline over time of sole practitioners in corporate contexts, has tended to concentrate professional provision within the sector. The surveys appear to testify to a general consolidation of information management in the corporate sector over time, with fewer information services concentrated in larger organisations. However because staffing levels are not consistently tracked through the surveys it is difficult to draw any reliable conclusions.

Another factor in the changing nature of information resources budgets has undoubtedly been a general shift from print to digital resources over the thirty years of the survey as discussed in the first part of this review (Tredinnick, 2019). This accompanied a general shift away from a purchase model for business information, to subscription and pay-for-access models. Budgets increase perhaps to accommodate a new range of digital resources, and to accommodate the provision of these on endusers desktops. This becomes an increasing feature of the provision of business information resources revealed by the surveys (see: Tredinnick, 2019). It is also clear that over time the organisations represented in the BIR Annual Survey have become more reliant on their own information resources, and less reliant on accessing public business information collections (theme 1 above). This is perhaps also reflected in increase in resource budgets over time. Nevertheless we can state that for the organisations represented in the BIR Annual Survey, the cost of information services increases significantly in real terms over the course of the survey. That in part reflects perhaps the increasing value of business information to commercial organisations. It does not necessarily reflect greater investment in employing information professionals. 
Despite this general increase in budgets over time, it is perhaps surprising to find that the provision of information services in the commercial sector is often framed by concerns about budgetary crises, and to some extent the impact of wider economic services. This is for example implicit in the 1992 and 1993 survey's habit of asking only about cuts to budgets (see above), but it is also a characteristic of the framing of the survey in general, and many of the qualitative contexts that emerge through the surveys. The 1992 survey for example notes that "the recession has had a significant impact on the expenditure on information resources of UK business libraries" (Headland Press, 1992: 4). A year later "effects of the recession are even more marked" (Headland Press, 1993: 3) with the ongoing effects emerging in training budgets and information broker budgets until much later (Headland Business Information, 1994; 1995). The credit crunch (Foster, 2008) and financial crisis (Foster, 2010; 2011; 2012) also feature in the surveys, most notably as a motivator for corporate re-organisation than in their direct budgetary consequences.

The perception of significant financial pressures on information services is evident throughout the period of the surveys, and this is perhaps somewhat in conflict with the apparent rise in investment in information services that is clear over the same period. This may reflect changes that have not been captured by the survey. We do know for example that information and knowledge management underwent considerable consolidation as a profession in the 1990s and 2000s, with many information centres in commercial organisations closing or being restructured into other organisational units. It may also reflect the rising cost of information resources compared with staffing budgets. These kinds of changes are not directly captured by the surveys. Rarely, for example, do the surveys capture the closure of an information services department (e.g. Foster, 2013) although this must have occurred many times. They are however arguably indirectly captured in the decline in participation in the survey over the period. This perhaps itself reveals the extent to which provision has contracted. Information management in the commercial sector is now increasingly confined to large business and financial services organisations.

\section{Theme 3: globalisation of business information}

These changes in the shape of the profession are also perhaps revealed by - and testify to - the increasing globalisation of business information work. In the first place, business information providers have increasingly consolidated into global brands. This is reflected in the focus on resources of the early surveys. Secondly, the contexts within which business information work takes places has increasingly shifted to organisations with global or international reach. Finally, the kind of information that is the raw materials of business information work is now drawn from global sources. It is no longer the case that national markets overwhelmingly dominate business information work, although there is still an obvious bias towards local contexts.

The BIR Annual Survey has predominantly focussed on the UK business information sector. As a consequence most demand for business information tracked by the survey has been for UK business information - particularly company financials, but also market research and financial markets. However the surveys also reveal a gradual globalisation of business information work. In 1992 around $66 \%$ of requests for information relating to business related to UK companies (Headland Press, 1992). There is a gradual decline in this until 1997 when this question is last asked, when around $61 \%$ of requests for company information was for to UK companies or corporations (Smith, 1997) (See figure 6). 
Figure 6: proportion of company information enquiries relating to UK businesses

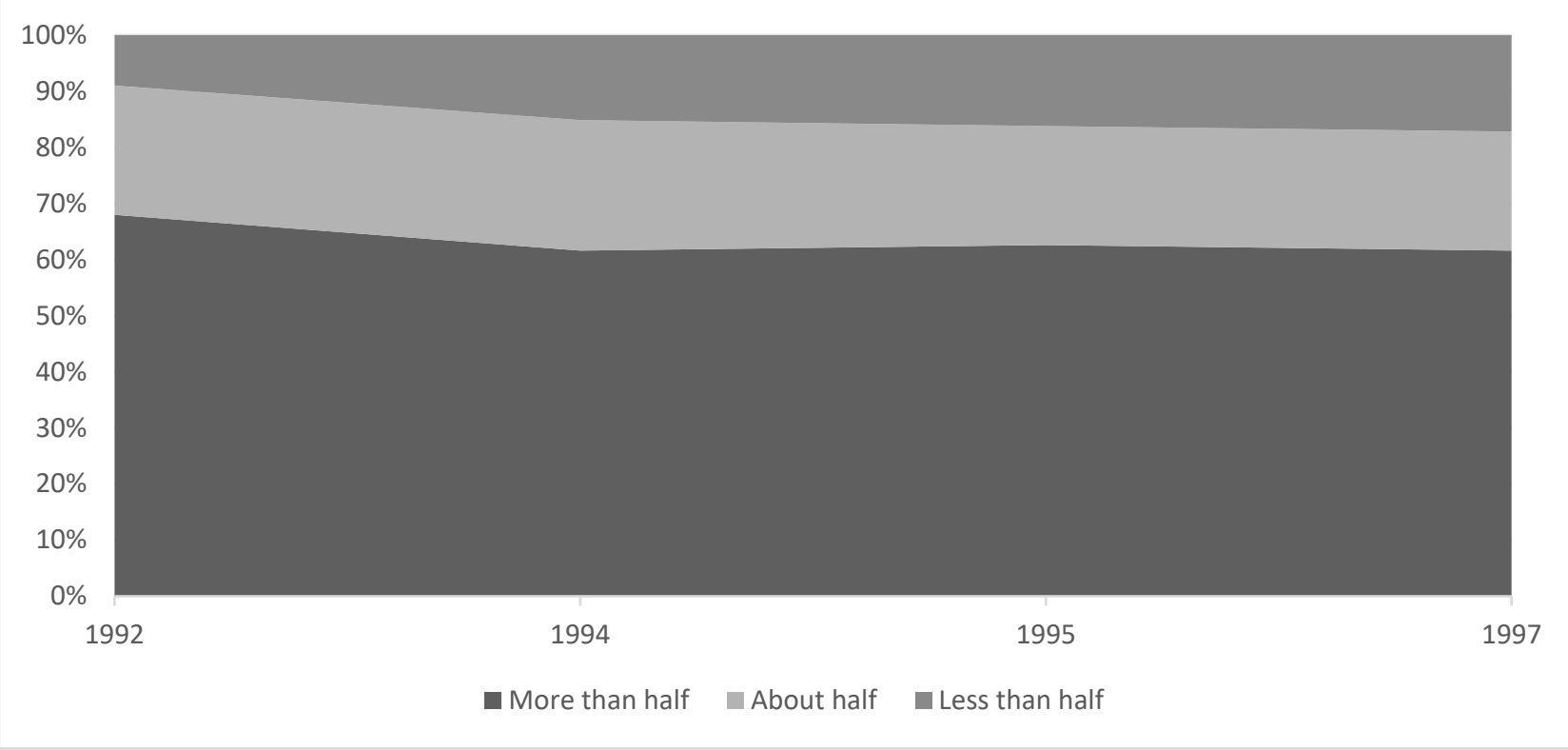

This trend is also captured in the commentary. In 1994 the survey reported that "There has been a significant increase in interest in information on overseas companies and markets (Headland Business Information, 1995a: 2). However the 1990s trends in internationalisation of information resources appears to have been short lived. In 2000 the survey reported that:

In the early 1990s, the survey picked up a strong growth in UK interest in overseas business information. Spurred on by the 1992 Single Market campaign, and soon afterwards by the opening up of the USSR, Eastern Europe and then China. Yet it appears to have been a short-term phenomenon, which has now run its course as demand for overseas business data has reverted to its lower historic level. It's possible that the next phase of the European Project could lead to a renewed interest in companies and markets in the other EU countries, but there's little sign of it at the moment. (Smith, 2000: 20)

Despite this into the 2000s the change in information work is revealed in other ways. First the language associate with international business information changes, with terms such as "international", "European" and "global" increasingly replacing "overseas" in both the commentary and qualitative answers. This perhaps suggests a change in perspective that reflects the globalisation of business. Secondly, from around 2001 qualitative comments record problems accessing information about companies in international contexts with increasing frequency. For example, the 1993 survey reports:

The company information sector is perceived as having the most gaps. Respondents claim they require more products containing information on unquoted and unlisted companies (corporate - investment trust), small companies (government), companies in less developed countries (corporate - business services), private European companies (corporate investment bank), pan-European official company data (corporate - information technology), and data on international and European SMEs (association). (Foster \& Foster, 2003: 20)

The 2006 survey notes that "The lack of European private company data, for example, is mentioned often" (Foster \& Foster, 2006: 97). In the early 2000s the problem of international market research also features increasingly prominently (Foster \& Foster, 2004; 2005). Through the early to mid-2000s the focus on international business information tends to be on the $\mathrm{EU}$, but into more recent years Asia, Australasia, and the Middle East begin to feature more prominently. In 2007 for example the survey reports that "another trend identified by a number of our respondents is the expansion of 
business in the emerging markets of Asia/Pacific and some parts of the Middle East" (Foster, 2007: 16). The following year one respondent reported "There's been an expansion in the demand for Asian data, and generally for global research support. We have increased our access to information on Asian companies and markets" (Foster, 2008: 28). Is becomes clear through the latter part of the survey that business information work is increasing undertaken in a global context within organisations that have international or global connections. This is significantly different from the UK business focus of the early surveys.

The design of the survey has recently changed to try to accommodate and capture some of these changes. In 2016 the survey reported that "Many of the participants represent global organizations, but I hope including more interviews with people based outside UK provides some additional insights and differing perspectives" (Carter, 2016: 10). By 2017 it was reported that "the breadth of the survey is now truly international, with respondents from UK, Europe, Asia, Australia and North America" (Carter, 2017: 122). Business Information Review has also increasingly published articles that reflect the global perspective of contemporary information and knowledge management in the commercial sector.

\section{Theme 4: offshoring and outsourcing information work.}

One aspect of the globalisation of information work captured by the surveys has been the rise in offshoring, and to a degree outsourcing. These did not feature as professional concerns in the surveys until 2007, although to some extent the use of information broker services which feature prominently before then explains this. Through the 1990s the surveys reveals a widespread but gradually declining use of broker services, which often supplement internal provision, and are occasionally explicitly used to even-out demand. From 2007 outsourcing and offshoring of information work begins to feature more significantly in the survey. In 2007 the survey reported:

The business information service arena is without doubt the leader in this field and there are a number of high profile companies, particularly in the banking and financial services sector, which have committed themselves to a wide-scale transfer of information and research tasks to staff in other countries (Foster, 2007: 18)

From 2007 until 2011 the proportion of respondents with a commitment to offshoring remains relatively consistent at around $20 \%$. Initially this use of offshoring is focussed in the investment banking sector, but from 2010 offshoring begins to feature more significantly in the planning of law firms. Until 2011 these offshoring strategies generally concentrate on India, but after that time Europe and the US feature more significantly in findings of the research. After around 2012 the impact of offshoring on the sector appears to settle-down, and it is raised less frequently as a specific issue, and more often as a part of outsourcing in general, and as part of integrated service strategies. Outsourcing and offshoring become part of the fabric of business information services.

Nevertheless use of offshoring strategies largely remains limited to a few key functions: back-office functions, basic business research, and analysis. This remains consistent throughout the surveys. The principle benefit of offshoring is of course the reduction of costs, and this is again is reiterated repeatedly in the surveys. However at the same time the perceived disadvantages remain fairly consistent over time. These include:

- Hidden costs of offshoring (Foster, 2007; 2008; 2011)

- Lack of real cost benefits (Foster, 2009; 2010)

- Concerns about confidentiality (Foster, 2007; 2008)

- Concerns about quality of work (Foster, 2007; 2008; 2009; 2012; 2015)

- Cultural barriers to understanding and communication (Foster, 2007; 2008)

- 'Ownership' of the service (Foster, 2008, 2015)

- Licensing restrictions on proprietary databases (Foster, 2008, 2009) 
Outsourcing and offshoring remains relevant to the present day; for example the 2015 report notes that "Outsourcing of services continues to grow overall and services come in many flavours" (Foster, 2015: 9). Nevertheless many of the explicit concerns over the value and difficulties of using outsourced services decline over time, as they become part of the way of doing information work.

\section{Theme 5: Changing skills in information work}

One of the most striking features of the survey is the ways in which the skills and competencies of information professionals have changed over time. It is fair to say that the skills associated with profession information work in the commercial sector do not come under a great deal of scrutiny for the first decade of the survey, emerging only in glimpses here and there. Where those glimpses do appear it is clear that the skills and competencies most valued tend to be technical - particularly with the rise of digital resource - and traditional - particularly business research. For example, the 1991 survey notes that "to have installed a CD-ROM player has been for several years the mark of true professionalism amongst many business librarians in the UK" (Headland Press, 1991: 18). In 1993 the survey asks about gaps in training provision for new and experience information work, and the responses emphasise technical and traditional skills including: technology updates; IT for beginners; online skills; computer skills and use of basis reference resources (Headland Press, 1993). Inadequate skills for coping with a changing information world do not feature as a concern until 1998 (Smith), and then are largely limited to non-information workers within organisations. There is perhaps a general assumption that the professional skills required for information work are those learned and acquired through professional practice.

However, from the 1990s this begins to change. This appears in part to be because the work of information professionals in the commercial sector is gradually diversifying beyond traditional roles. One of the key changes to information work tracked by the survey has been an increase in training functions, particularly associated with the migration of information resources to end-user desktops. Figure 7 below tracks the frequency of "training" as an issue in the surveys over time. It reveals a clear peak in interest in training issues around the early 2000 s, and a smaller peak in more recent years.

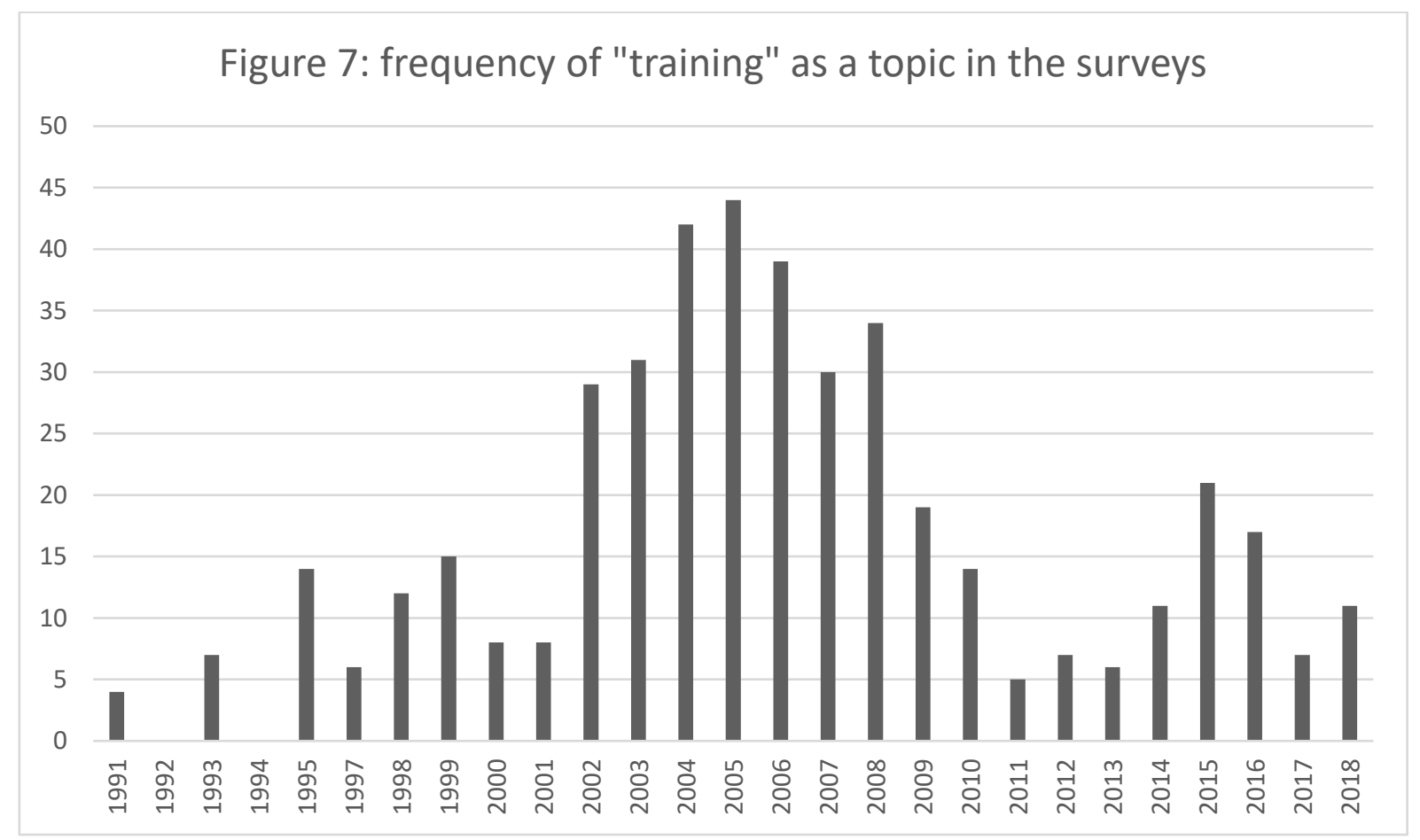


What the chart does not reveal is that the focus of training in the surveys shifts from training information professional to undertake information work, to training end users in basic information skills and information literacies. Over time information professionals in the commercial sector take on more responsibility for the training of end-users, and this has a number of clear consequences that are revealed by the survey. These include a reduction in the volume of routine enquiries, balanced out by greater involvement in complex or difficult enquiries requiring more advanced business research skills and more involvement in analysis. They also include a greater emphasis on advising end-users on appropriate sources and resources, and on soft skills, including communication skills, business awareness, and commercial acumen.

These changes to information roles begin to emerge in the survey in 1999, which reports:

"Comments indicate that their roles are already changing to accommodate higher user expectations: they are offering more training in information skills, acting as a guide to the best sources to save users having to waste time surfing to find what they need and providing better quality tailored services. Many librarians welcome the shift from repetitive basic searching and being able to offload it to users, in favour of using more advanced information skills and in training users" (Smith, 1999: 12)

By 1998 over ninety-percent of information services represented in the survey are providing training of one kind or another to end-users. The survey records the significance of this transformation:

Perhaps one of the most significant changes in the 18 years of this Survey has been in the provision of training in the use of information within companies. From a time in the print era when the Information/Research Department would do all the work of information discovery and delivery to the user, we have moved to a situation dominated almost totally by electronic business information. Much of this in most companies is provided to the clients' desktop over high capacity networks. As this has happened, alongside it has grown a responsibility for Information Services staff to provide some kind of training and awareness in what products to use and how to use them. (Smith, 1998: 28)

This increasing involvement in training remains consistent through subsequent services, but is seen as complimentary to commercial information services, rather than in competition to the role of information professionals. For example one respondent in 2001 stated that "researcher skills are still needed to locate and understand requests" (Smith, 2001: 12), and this belief that information professions retain expertise and high level skills that continue to be of value to organisations in common. The training roles of information professionals often emerge as ad hoc functions rather than as organised training programmes; for example in 2007 one respondent commented that "'Training has to be discreet, obliquely worked in to day-to-day interaction with users" (Foster, 2007: 25). Furthermore a focus on training in specific products and resources broadens from around 2006 to training in information literacy and general business research skills. To some degree the emergence of training as a key professional competency may just reflect a formalising of functions that information professionals have always undertaken.

Training emphasises the other ways in which the role of information professionals changes into the 2000 s as a consequence of technological change. Demand for soft skills and commercial acumen becomes more apparent from the early 2000s. For example the 2003 survey reports the following comments in relation to the skills-base of applicants and new recruits (Foster \& Foster. 2003: 21):

- 'In general, they are not sufficiently appreciative of the need for pro-active approach to keeping up-to-date, gaining product knowledge.

- Need to leave the territory of the information department and meet people within the organization. Need to develop presentation and self-marketing skills';

- 'Lack of commercial awareness of graduates'

Commercial acumen and business knowledge feature more prominently over time. In 2004 one respondent complained that LIS graduate have "no business knowledge; little commercial skill, 
knowledge" (Foster \& Foster, 2004: 33). By 2016 one of the most important qualities of information professionals in the commercial sector is this wider business acumen. The 2018 survey reports as one of its key finding "being commercially minded both, in what is delivered, and how it is delivered, is critical in order to remain relevant and grow with the organisation" (Carter, 2016: 9).

The importance of soft skills (influencing, coaching, negotiating, business awareness) are first mentioned in 2004 (Foster \& Foster, 2004: 33), and communication skills and presentation skills from 2005 (Foster \& Foster, 2004: 20). These become of increasing importance to the role of information processionals in subsequent surveys. Towards the end of the period we find that customer and stakeholder management become increasingly important in perceptions of key skills (Carter, 2018). In addition towards the end of the period we find evaluation skills become increasingly important that simple research skills, not just relating to the evaluation of products and services, but also to the evaluation of the accuracy and reliability of information itself. The 2018 survey makes this clear: "survey participants are clear that the ability to ensure data is of highest quality and integrity is a critical skill for information professionals" (Carter, 2018: 99).

\section{Theme 6: Information quality and reliability}

This emphasis on evaluation skills tends to highlight the question of trust in the information sources used by information professionals in the commercial sector. The quality and reliability of business information has been an occasional concern of the BIR Annual Survey. The first time in which the quality and reliability of business information is addressed is in 1992, and at that time there is a relatively positive outlook. The survey reports:

"The alleged inaccuracy of business data has been a hot topic in business library circles in
recent years, reflecting the wider business interest in the quality of goods and services. The
table above indicates that data accuracy is not a problem for most business librarians. The
responses to the question below seem to indicate that, far from things getting worse, as is
claimed, business librarians perceive the accuracy of data they are handling as improving.

The adoption of web-based services in the late nineteen-nineties appears to increase concerns around information quality and reliability. This emerges first in qualitative comments in 1997, which highlight variable quality sources as a concern. A year later the survey reports "the use of the Web for business information research does, of course, still have major problems, principally the variable quality of much of the content" (Smith: 1997: 6). The quality of company data, particularly in international markets, is sometime questioned (e.g. Smith, 2002: 19). More recently the survey has reflected concerns about fake news and the impact of disinformation (Carter, 2017). Nevertheless there is a general perception throughout the surveys that the quality of business information sources is a concern in only specific contexts, and that information professionals play a key role in ensuring business decisions are based on high quality, accurate, and reliable information.

\section{Theme 7: Rising up the value chain}

The title for this theme is taken directly from the sub-title of the 2001 Business Information Review Annual Survey (Foster, 2007). It captures a general shift in the relationship of information services centres to the organisations that host them. In 1991 when the survey began, information service centres were generally regarded as a cost to business. This perception perhaps drives the contraction and consolidation that is apparent in the 1990s and early 2000s. However it is very clear from the surveys that contemporary information service centres identify their value not only in providing information, but in adding value to that information, and as a consequence contributing to the delivery of business processes in a meaningful and valuable way.

The idea of value-added services appears a couple of times in earlier surveys, but the first significant mention of adding value to the organisation appears in 2001 in qualitative comments from two respondents. In 2005 the survey asked for the first time whether individual departments seek to add value to information; at that time around $40 \%$ of respondents said they did (Foster \& Foster, 2005). 
Two years later in 2007 that had risen to $75 \%$ of respondents (Foster, 2007). By 2013 the message of the survey was very stark: "add value or die" (Foster, 2013: 8). Through this period the ways in which information professionals are adding value to the work that they do incorporates a range of expanded roles: analysing, compiling and reporting research, undertaking increasingly in-depth research, and becoming more involved in information strategy and policy across the organisation.

Adding value and rising up the value chain is linked with the diversification of professional roles and the development of higher-level research and analysis skills. The 2003 survey reports:

"With end-users doing the simple stuff themselves, LIS departments are being asked to field the more difficult, in-depth enquiries and research questions. This is allowing them to add more value than in previous eras" (Foster \& Foster, 2003: 13)

A similar point is made by one respondent to the 2005 survey:

More data has also been put on the desktop and some 'distributed marketing' roles have been created, where users in some departments have been given access to additional sources. The information staff now focuses on more value added services (Foster \& Foster, 2005:19).

The survey therefore reveals the way in which technological change brings about new opportunities, and perhaps creates richer working lives in many instances. This trend continues for the remainder of the period covered by the surveys. For example, in 2015 the survey reports that all respondents "trying to move up the value-added chain in one way or another, and some are trying to position themselves at the heart of their companies" (Foster, 2015: 10). Information services centres within corporate contexts seek to reposition themselves as integral parts of the business.

\section{Conclusions}

The BIR Annual Surveys testify to significant change in the business information sector over a period that has witnessed significant economic problems, globalisation and the rise of outsourcing and offshoring, and a fundamental shift in the structure of business information products, services, and research arising from technological change. In some ways the changes in the profession over this time have been unsettling. There has been a contraction and consolidation of information work in the corporate sector. The wider economic context has often impacted disproportionately on the working lives of information professionals. Yet not all of the changes have been negative. Information professionals in the corporate sector are now generally undertaking more diverse and more demanding work, exploiting higher-level analytical skills, taking a role in strategic decision-making, and in supporting and training workers across organisations. The Business Information Review Annual Survey has tracked these trends across three decades of unprecedented change.

\section{Appendix 1: overview of BIR Annual Survey}

The following table provides an overview of the publication record of the BIR Annual Survey.

\begin{tabular}{|l|l|l|l|l|l|l|}
\hline Survey & No. & Date published & $\begin{array}{l}\text { Volume } \\
\text { (issue) }\end{array}$ & Names Author & Methodology & Pages \\
\hline
\end{tabular}




\begin{tabular}{|c|c|c|c|c|c|c|}
\hline 1991 & 1 & July 1991 & $8(1)$ & Headland Press & $\begin{array}{l}\text { General postal } \\
\text { questionnaire }\end{array}$ & 11 \\
\hline 1992 & 2 & July 1992 & $9(1)$ & Headland Press & $\begin{array}{l}\text { General postal } \\
\text { questionnaire }\end{array}$ & 11 \\
\hline 1993 & 3 & October 1993 & $10(2)$ & Headland Press & $\begin{array}{l}\text { General postal } \\
\text { questionnaire }\end{array}$ & 12 \\
\hline 1994 & 4 & January 1995 & $11(3)$ & $\begin{array}{l}\text { Headland Business } \\
\text { Information }\end{array}$ & $\begin{array}{l}\text { General postal } \\
\text { questionnaire }\end{array}$ & 14 \\
\hline 1995 & 5 & October 1995 & $12(2)$ & $\begin{array}{l}\text { Headland Business } \\
\text { Information }\end{array}$ & $\begin{array}{l}\text { General postal } \\
\text { questionnaire }\end{array}$ & 27 \\
\hline 1997 & 6 & March 1997 & $14(1)$ & Gerry Smith & $\begin{array}{l}\text { General postal } \\
\text { questionnaire }\end{array}$ & 14 \\
\hline 1998 & 7 & March 1998 & $15(1)$ & Gerry Smith & $\begin{array}{l}\text { General postal } \\
\text { questionnaire }\end{array}$ & 17 \\
\hline 1999 & 8 & March 1999 & $16(1)$ & Gerry Smith & $\begin{array}{l}\text { General postal } \\
\text { questionnaire }\end{array}$ & 19 \\
\hline 2000 & 9 & March 2000 & $17(1)$ & Gerry Smith & $\begin{array}{l}\text { General postal } \\
\text { questionnaire }\end{array}$ & 17 \\
\hline 2001 & 10 & March 2001 & $18(1)$ & Gerry Smith & $\begin{array}{l}\text { General postal } \\
\text { questionnaire }\end{array}$ & 19 \\
\hline 2002 & 11 & March 2002 & $19(1)$ & $\begin{array}{l}\text { Allan Foster \& Pam } \\
\text { Foster }\end{array}$ & $\begin{array}{l}\text { General postal } \\
\text { questionnaire }\end{array}$ & 18 \\
\hline 2003 & 12 & March 2003 & $20(1)$ & $\begin{array}{l}\text { Allan Foster \& Pam } \\
\text { Foster }\end{array}$ & $\begin{array}{l}\text { General postal and } \\
\text { electronic } \\
\text { questionnaire }\end{array}$ & 20 \\
\hline 2004 & 13 & March 2004 & $21(1)$ & $\begin{array}{l}\text { Pam Foster \& Allan } \\
\text { Foster }\end{array}$ & $\begin{array}{l}\text { General postal and } \\
\text { electronic } \\
\text { questionnaire }\end{array}$ & 23 \\
\hline 2005 & 14 & March 2005 & $22(1)$ & $\begin{array}{l}\text { Pam Foster \& Allan } \\
\text { Foster }\end{array}$ & $\begin{array}{l}\text { Targeted and } \\
\text { general postal and } \\
\text { electronic } \\
\text { questionnaire }\end{array}$ & 23 \\
\hline 2006 & 15 & June 2006 & $23(2)$ & $\begin{array}{l}\text { Pam Foster \& Allan } \\
\text { Foster }\end{array}$ & $\begin{array}{l}\text { Targeted and } \\
\text { general postal and } \\
\text { electronic } \\
\text { questionnaire }\end{array}$ & 25 \\
\hline 2007 & 16 & March 2007 & $24(1)$ & Allan Foster & $\begin{array}{l}\text { Targeted } \\
\text { interviews }\end{array}$ & 17 \\
\hline 2008 & 17 & March 2008 & $25(1)$ & Allan Foster & $\begin{array}{l}\text { Targeted } \\
\text { interviews }\end{array}$ & 19 \\
\hline 2009 & 18 & March 2009 & $26(1)$ & Allan Foster & $\begin{array}{l}\text { Targeted } \\
\text { interviews }\end{array}$ & 18 \\
\hline 2010 & 19 & March 2010 & $27(1)$ & Allan Foster & $\begin{array}{l}\text { Targeted } \\
\text { interviews }\end{array}$ & 19 \\
\hline 2011 & 20 & March 2011 & $28(1)$ & Allan Foster & $\begin{array}{l}\text { Targeted } \\
\text { interviews }\end{array}$ & 17 \\
\hline 2012 & 21 & March 2012 & $29(1)$ & Allan Foster & $\begin{array}{l}\text { Targeted } \\
\text { interviews }\end{array}$ & 20 \\
\hline 2013 & 22 & March 2013 & $30(1)$ & Allan Foster & $\begin{array}{l}\text { Targeted } \\
\text { interviews }\end{array}$ & 19 \\
\hline 2014 & 23 & March 2014 & $31(1)$ & Allan Foster & $\begin{array}{l}\text { Targeted } \\
\text { interviews }\end{array}$ & 27 \\
\hline 2015 & 24 & March 2015 & $32(1)$ & Allan Foster & $\begin{array}{l}\text { Targeted } \\
\text { interviews }\end{array}$ & 28 \\
\hline 2016 & 25 & March 2016 & $33(1)$ & Denise Carter & $\begin{array}{l}\text { Targeted } \\
\text { interviews }\end{array}$ & 10 \\
\hline
\end{tabular}




\begin{tabular}{|l|l|l|l|l|l|l|}
\hline 2017 & 26 & $\begin{array}{l}\text { September } \\
2017\end{array}$ & $34(3)$ & Denise Carter & $\begin{array}{l}\text { Targeted } \\
\text { interviews and } \\
\text { general } \\
\text { questionnaire }\end{array}$ & 16 \\
\hline 2018 & 27 & $\begin{array}{l}\text { September } \\
2018\end{array}$ & $35(3)$ & Denise Carter` & $\begin{array}{l}\text { Targeted } \\
\text { interviews and } \\
\text { general } \\
\text { questionnaire }\end{array}$ & 17 \\
\hline
\end{tabular}

\section{Appendix 2: Key professional findings:}

The table below lists a summary of selected profession-related findings from each published BIR annual survey. These are not exhaustive and readers should consult the original reports for more detail. Because of its earlier focus on resources, professional findings are not consistently recorded by the surveys before 2002 .

\begin{tabular}{|c|c|}
\hline Survey year & Key professional findings \\
\hline 2002 & $\begin{array}{l}\text { - In those organizations committed to knowledge management, libraries } \\
\text { and } \\
\text { - information departments are playing an integral part } \\
\text { - Despite the plethora of products, business information professionals } \\
\text { claim there are still gaps in the market } \\
\text { - Improving access, training and support is the main service priority for } \\
\text { corporate business librarians over the next two years. }\end{array}$ \\
\hline 2003 & $\begin{array}{l}\text { - Sparing staff to attend training courses is a critical problem, more so than } \\
\text { the cost of the course itself } \\
\text { - Observations on the quality of recruitment candidates, both professional } \\
\text { and support, are generally favourable } \\
\text { - There are growing initiatives to improve the information literacy of end- } \\
\text { users }\end{array}$ \\
\hline 2004 & $\begin{array}{l}\text { - Nearly half of respondents say their organization has a recognisable } \\
\text { information strategy } \\
\text { - Perceived lack of resources covering unincorporated private } \\
\text { European/international company data, historical share price data and } \\
\text { share ownership data }\end{array}$ \\
\hline 2005 & $\begin{array}{l}\text { - Offshoring issues highlighted for first time } \\
\text { - Strategic priorities are managerial, political and service/content } \\
\text { development } \\
\text { - Majority of information managers assess effects of their services on the } \\
\text { organization }\end{array}$ \\
\hline 2006 & $\begin{array}{l}\text { - Stable and improving budgetary and staffing position; } \\
\text { - More outsourcing and offshoring; } \\
\text { - Quality of new staff improving; } \\
\text { - KM increasingly recognized and mainstreamed; }\end{array}$ \\
\hline 2007 & $\begin{array}{l}\text { - There is a distinct trend for information services to move up the value chain } \\
\text { through more evaluation and analysis functions. } \\
\text { - The majority (70\%) of business information services are involved in } \\
\text { supporting compliance work. }\end{array}$ \\
\hline 2008 & $\begin{array}{l}\text { With more information rolled out to the clients' desktops, the services are } \\
\text { all working to add value through a variety of approaches, including training, } \\
\text { evaluation and analysis, business and client development, and generally } \\
\text { undertaking more complex work }\end{array}$ \\
\hline
\end{tabular}




\begin{tabular}{|c|c|}
\hline & $\begin{array}{l}\text { - Almost all services are committed to training users in the discovery and use } \\
\text { of digital business information sources } \\
\text { - The organization, management, and sometimes realignment of services is } \\
\text { the highest strategic priority. }\end{array}$ \\
\hline 2009 & $\begin{array}{l}\text { - Constant search for ways for Information Department to add more value to } \\
\text { the business. } \\
\text { - Vendor management and relationships: respondents demand more } \\
\text { creativity and understanding on charging levels and flexibility } \\
\text { - Information risks such as password misuse, Intellectual Property (IP) and } \\
\text { copyright breaches and licensing violations should be better understood } \\
\text { and managed }\end{array}$ \\
\hline 2010 & $\begin{array}{l}\text { - Increasing and imaginative ways that information services are adding } \\
\text { value including undertaking analytical financial and market work } \\
\text { - Knowledge sharing is higher on the agendas of some companies } \\
\text { - Deployment of innovative techniques such as the use of stories to } \\
\text { disseminate good practice and knowledge sharing }\end{array}$ \\
\hline 2011 & $\begin{array}{l}\text { - Distributed responsibility for information/knowledge management in } \\
\text { globally distributed businesses rather than more integrated central control. } \\
\text { - Information departments getting much more involved in internal data and } \\
\text { knowledge processes especially high profile compliance work. } \\
\text { - Organization and management issues dominate information managers' } \\
\text { strategic objectives in next two years. }\end{array}$ \\
\hline 2012 & $\begin{array}{l}\text { - Externalization - more working with partners, third parties, individual } \\
\text { contractors. Implications for licensing, vendor relations and support. } \\
\text { - Encouraging collaboration - explicit/tacit knowledge, removing silos, } \\
\text { encouraging communities of practice, the rise of SharePoint. } \\
\text { - Enhancing analytical skills of IS/KM staff, either direct or via outsourcing } \\
\text { contractor. }\end{array}$ \\
\hline 2013 & $\begin{array}{l}\text { - Very mixed fortunes of respondents, from modest expansion to } \\
\text { disbandment. } \\
\text { - Serious senior management scepticism of the traditional centralized } \\
\text { information services model. } \\
\text { - Outsourcing, on or offshore, still a popular organizational model, with } \\
\text { notable successes and failures. } \\
\text { - The notably successful services are finding new and imaginative ways of } \\
\text { adding value, sometimes well outside traditional IS/IM boundaries. }\end{array}$ \\
\hline 2014 & $\begin{array}{l}\text { - Global operations for many services, with varying central control and a } \\
\text { mix of organizational models. } \\
\text { - A commitment to outsourcing by some } 50 \text { per cent of respondents, some } \\
\text { very mature arrangements, with a shifting balance of responsibilities } \\
\text { between onshore and offshore staff. } \\
\text { - Continuing doubts about adequacy of professional education given these } \\
\text { changing business and technology environments. } \\
\text { - Many positive developments in knowledge sharing, social media, the use } \\
\text { of stories and growing use of enterprise-wide collaborative systems. }\end{array}$ \\
\hline 2015 & $\begin{array}{l}\text { - Outsourcing of services continues to grow overall and services come in } \\
\text { many flavours. } \\
\text { - All respondents trying to move up the value-added chain in one way or } \\
\text { another, and some are trying to position themselves at the heart of their } \\
\text { companies. } \\
\text { - Movement towards 'anytime, anywhere, any device' access to information } \\
\text { and data. } \\
\text { - Growing awareness of information risk assessment and management. } \\
\text { Better metrics are being developed to understand usage and outputs } \\
\text { (including the provision of dashboard tools), if not of outcomes. }\end{array}$ \\
\hline
\end{tabular}




\begin{tabular}{|c|c|}
\hline 2016 & $\begin{array}{l}\text { - Being commercially minded both, in what is delivered, and how it is } \\
\text { delivered, is critical in order to remain relevant and grow with the } \\
\text { organisation. } \\
\text { - Having a future-focused vision and horizon planning skills are becoming } \\
\text { essential for the industry information professional now and in the future. }\end{array}$ \\
\hline 2017 & $\begin{array}{l}\text { - Some information leaders are defining what they deliver as future } \\
\text { awareness rather than current awareness. } \\
\text { - Information leaders understand that information skills, for example } \\
\text { information literacy skills, have a value in themselves. They not only enable } \\
\text { the information professional to provide the right information at the right time } \\
\text { but are transferable skills which have the potential to be monetised. } \\
\text { - Realising the potential from connecting and linking data and datasets } \\
\text { creatively is a work in progress for information professionals across all } \\
\text { sectors. }\end{array}$ \\
\hline 2018 & $\begin{array}{l}\text { - Information teams see their core deliverables as content management, } \\
\text { training on information-related databases, and research and analysis. } \\
\text { - Information teams in banking and financial organisations indicate they } \\
\text { feel they impact business decisions in their organizations more directly } \\
\text { than information teams in other sectors. } \\
\text { Data quality, and trust and confidence in data, are concerns for } \\
\text { information professionals; survey participants are clear that the ability to } \\
\text { ensure data is of highest quality and integrity is a critical skill for } \\
\text { information professionals. } \\
\text { - Information professionals see research analysis developing further to } \\
\text { include providing implications and deductions; and this will require more } \\
\text { confidence. }\end{array}$ \\
\hline
\end{tabular}

\section{Bibliography: BIR Annual Surveys}

Headland Press (1991), Business Information Resources 1991 Survey, Business Information Review, 8 (1): $11-21$.

Headland Press (1992), Business Information Resources 1992 Survey, Business Information Review, 9 (1): 3 - 13.

Headland Press (1993), Business Information Resources 1993 Survey, Business Information Review, 10 (2): 2 - 13.

Headland Business Information (1995a), Business Information Resources Survey, Business Information Review, 11 (3): 2- 15.

Headland Business Information (1995b), Business Information Resources Survey, Business Information Review, 12 (2): 2-28.

Smith, G. (1997), Business Librarians Embrace the Internet: Annual Business Information Resources Survey, Business Information Review, 14 (1): 1 - .

Smith, G. (1998), Annual Business Information Resources Survey 1998, Business Information Review, (1): 5-21.

Smith, G. (1999), Business Information in the Internet Age: The Annual Business Information Resources Survey 1999, Business Information Review, 16 (1): 5 - 23. 
Smith, G. (2000), Business Information in Transition: The Business Information Resources Survey 2000, Business Information Review, 17 (1): 5 - 21.

Smith, G. (2001), The New Information Economy Takes Shape: The Business Information Resources Survey 2001, Business Information Review, 18 (1): 5 - 23.

Foster, A. \& Foster, P. (2002), Business Information in the End-User Age: Business Information Resources Survey 2002, Business Information Review, 19 (1): 5 - 22.

Foster, A. \& Foster, P. (2003), Empowering the End-User: Business Information Resources Survey 2003, Business Information Review, 20 (1): 5 - 24.

Foster, P. \& Foster, A. (2004), Delivering Services Under Financial Pressure: Business Information Resources Survey 2004, Business Information Review, 21 (1): 13 - 35.

Foster, P. \& Foster, A. (2005), Adapting to Change: Business Information Resources Survey 2005, Business Information Review, 22 (1): $15-37$.

Foster, P. \& Foster, A. (2006), Stability is not Immobility: Business Information Resources Survey 2006, Business Information Review, 23 (2): 83 - 107.

Foster, A. (2007), Moving Up the Value Chain: Business Information Resources Survey 2007, Business Information Review, 24 (1): $13-29$.

Foster, A. (2008), Business Information Survey, Business Information Review, 25 (1): 13 - 35.

Foster, A. (2009), Battening Down the Hatches: Business Information Survey 2009, Business Information Review, 26 (1): $10-27$.

Foster, A. (2010), The Boss Just Said 'Do More with Less!': The Business Information Survey 2010, Business Information Review, 27 (1): 8 - 26.

Foster, A. (2011), Let's Save the Company Money - the New Orthodoxy: The Business Information Survey 2011, Business Information Review, 28 (1): 8 - 24.

Foster, A. (2012), Let's Integrate - Information Services, Content, Technologies, and Collaboration: The Business Information Survey 2012, Business Information Review, 29 (1): 9 28.

Foster, A. (2013), Add Value or Die: The Fate of Corporate Information Services: The Business Information Survey 2013, Business Information Review, 30 (1): 8 - 26.

Foster, A. (2014), The Game is Changing: The Business Information Survey 2014, Business Information Review, 31 (1): $14-40$.

Foster, A. (2015), 'Moving the Corporate Needle' - How Are We Doing: the Business Information Survey 2015, Business Information Review, 32 (1): 10 - 37.

Carter, D. (2016), Demonstrating a Commercial Mindset: The 2016 Business Information Survey, Business Information Review, 33 (1): 9 - 18.

Carter, D. (2017), Creativity in Action - the Information Profession is Poised to Exploit the Fourth Industrial Revolution: The Business Information Survey 2017, Business Information Review, 34 (3): $122-137$.

Carter, D. (2018), How Real is the Impact of Artificial Intelligence? The Business Information Survey 2018, Business Information Review, 35 (3): 99 - 115. 


\section{Bibliography: Other cited works}

Cipfa (2018), 'Libraries lose branches and staff as spending continues to drop', Chartered Institute of Public Finance and Accountancy, available at: https://www.cipfa.org/about-cipfa/press-

office/archived-press-releases/2018-press-releases/libraries-lose-branches-and-staff-as-spendingcontinues-to-drop [accessed: $01^{\text {st }}$ November 2019]

Tredinnick, L. (2019), Twenty-nine years of the BIR Annual Survey part 1: Technological change, Business Information Review, 36 (3): 106-124. 